\title{
Phytomedicine and Allied Compounds in Both Human and Animal Healthcare
}

\author{
Kihagi $\mathrm{RW}^{2}$, Amuka $\mathrm{O}^{1 *}$, Machocho $\mathrm{AK}^{2}$ and Wafula $\mathrm{AW}^{2}$ \\ ${ }^{1}$ Department of Applied Plant Sciences, School of Agriculture and Food Security, Maseno University, Kenya
}

${ }^{2}$ Department of Chemistry, School of Pure and Applied science, Kenyatta University, Kenya

*Corresponding author: Amuka 0, Department of Applied Plant Sciences, School of Agriculture and Food Security, Maseno University, Kenya

\section{ARTICLE INFO}

Received: 幽 January 24, 2019

Published: 幽 February 07, 2019

\section{ABSTRACT}

Citation: Kihagi RW, Amuka 0*, Machocho AK, Wafula AW. Phytomedicine and Allied Compounds in Both Human and Animal Healthcare. Biomed J Sci \& Tech Res 14(2)-2019. BJSTR. MS.ID.002511.

\section{Introduction}

Worldwide plants have been used for curative purposes from time immemorial. It is estimated by WHO that $80 \%$ of the population majority of this in developing countries, still rely on plant-based medicine for primary healthcare Evans [1]; Farnsworth [2]. WHO further estimated that over $80 \%$ of the population residing in developing countries depends directly on plants for their primary medical requirements Czygan [3]; WHO [4]. This is attributed to the fact that plant-derived medicines can be easily accessed and are also cheap Amin et al. [5]; Ramawat et al. [6]; WHO [5]. The use of some crude extracts whose specific evaluations have not been done could lead to serious complications, overdose and intake of toxic substances [7-10]. Ineffective herbs could also be used as a matter of belief or tradition Baker et al. [11]. In most countries, use of herbal medicine continues to coexist with modern Pharmacology Ernest [12]. The worldwide upsurge in the use of herbal preparations and active ingredients isolated from medicinal plants in healthcare Jassim et al. [13] is due to increased side effects, lack of curative treatment for several chronic diseases, high cost of new drugs, microbial resistance and emerging diseases Humber [14].

This is indicated by the growing popularity of Traditional Chinese Medicine (TCM) and Ayuverdic medicine of India Jiang et al. [15]; Dubey et al. [16]. In Africa, the use of traditional medicine is very high as indicated by the fact that between 70 and $80 \%$ of the population depend on herbal preparations for primary healthcare with little or no scientific information on efficacy and side effects Kokwaro [17-25]. Furthermore, even the people of the developed world are also dependent directly or indirectly on plants for their health care. In the United States, $25 \%$ of the prescriptions given from community pharmacies consisted of plant extracts or active ingredients of plant origin Cragg et al. [26]. In Dar es
Salaam, Tanzania, 21\% of patients who visited public Hospitals had consulted a traditional healer before they came to hospital De Boer et al. [27]. Plant-derived medicines are offered/taken in the form of tinctures, teas, poultices and powders, depending on the knowledge of the use and application method of a particular plant for a given ailment Fennell et al. [28]; Balunas et al. [29].

It has also been demonstrated in food that Plant extracts like Polyphenols can successfully be used in food conservation thus extend self-life of such products that could otherwise go to waste due to spoilage Papuc et al. [30]. In Kenya, debate on incorporation of traditional medicine into primary health care has been going on for a while now [31-40]. There is an attempt to make a law to regulate the practice of traditional medicine by way of legislation. The Traditional Health Practitioners Bill, 2014 was published on the February 2014 and was tabled before the National Assembly by the then Chairperson of the Health Committee Rachael Nyamai. The Bill went through the first reading on $3^{\text {rd }}$ June 2014 and the Committee further tabled its report on the deliberations regarding the said bill on $25^{\text {th }}$ April 2015 but since then there has been no progress. If the Bill is passed into law it seeks to provide for the training, regulation and licensing of traditional practitioners so as to regulate their practice. Further, it seeks to set up traditional health practitioners' council which is a body mandated with regulation. It also seeks to set up a Disciplinary Committee that will discipline practitioners as well as setting offenses and penalties under the said law [41-47].

Traditional societies in Africa had devised methods of providing every individual in the community with essential healthcare through acceptable and accessible means by the application of indigenous resources such as plants, animals and minerals Chhabra et al. [47]. Besides, herbal medicine takes into account 
every country's socio-cultural background. the western societies have capitalized on this fact to the ignorance of other societies and either using the plant products . Of late, despite emphasis being put in research of synthetic drugs, a certain interest in medicinal plants has been reborn $[48,49]$. This is partly due to the fact that many synthetic drugs are potentially toxic and not free of side effects on the host and that the effectiveness of many herbal medicines is now an accepted fact Thomson [50]; Geddes [51]. Further, herbal preparations constitute valuable natural resource from which chemicals of great potential interest for medicine, agriculture, industry and other areas can be identified and isolated [52-65]. Such valuable drugs such as atropine (1), reserpine (2), quinine (3) and morphine (4) were discovered from traditional herbal remedies (Figure 1) Sneader [66], Ji et al. [67].

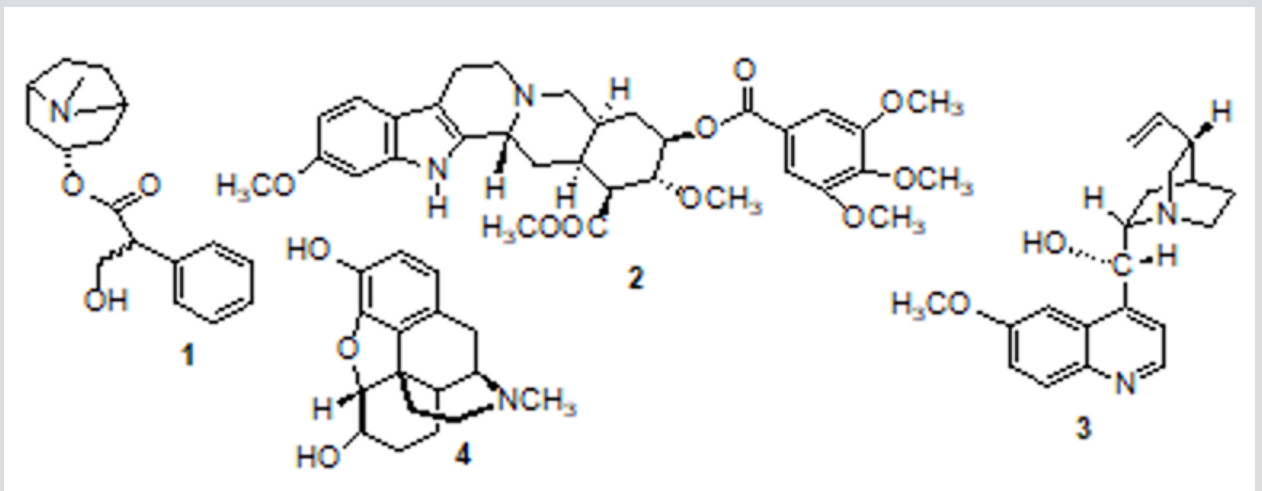

Figure 1: Traditional Herbal Remedies.

It is estimated that about $25 \%$ of the drugs prescribed worldwide are derived from plants and 121 such active compounds are in use Sahooetal [68]. Between 2005 and 2007, 13 drugs derived from natural products were approved in the United States. More than 100 natural product-based drugs are in clinical studies Li et al. [69], and out of the total 252 drugs in the World Health Organization's (WHO) essential medicine list, 11\% are exclusively of plant origin Sahooetal [68]. Microbiologists all over the world have been prompted to search for formulations of new antimicrobial agents and evaluation of the efficacy of natural plant products as a substitute for chemical antimicrobial agents Pandian et al. [70] Such moves have been prompted by insurmountable resistances to antibiotics that have been experienced in the past [71-85]. Many microorganisms and plants produce compounds that are not related to the basic metabolism of the producing organism called secondary metabolites as their defense mechanism. Many of these products play important roles as therapeutics and stimulants feed additives among others, Hans [86].

Medicinal plants are well-known natural sources for the treatment of various diseases since antiquity [87-90]. About 20,000 plant species used for medicinal purposes are reported by the World Health Organization (WHO) Gullece et al [91]; Maregesi [92]. Furthermore, natural products, either crude compounds, or as standardized plant extracts, provide unlimited opportunities for new drug leads because of the unmatched availability of chemical diversity Cos et al. [93]. In the past, the wide range of antimicrobial agents from lower organisms and synthetic drugs sufficed in the treatment or control of infectious diseases, but currently there is a problem of microbial drug resistance and there is an increase of opportunistic infections especially with acquired immune deficiency syndrome (AIDS) patients and individuals on immunosuppressive chemotherapy. Many antifungal and antiviral drugs are of limited use due to toxicity, while other viral diseases have not yet found a cure [94-100]. These problems pose a need of searching for more new drug substances. Most of the plants used traditionally for treatment of various ailments locally have not been studied scientifically for their efficacies and side effects Kokwaro.

Ethno-botanical information is slowly dying out due to lack of vertical transmission to young generation as people holding the information on these plants are fast dying out. There is also imminent loss of some of these plant species due to population pressure and over exploitation without proper conservation policies. Preparations, handling and storage of crude extracts from these plants could lead to decomposition or transformation into ineffective and/or harmful products Baker et al. [19], Dutra et al. [101]. In Africa, data available, indicate that medicinal plants can also be used to earn foreign exchange by exporting them to the western world Busia. It has been documented that the huge pharmaceutical significance of many tropical medicinal plants could be utilized to generate foreign exchange as well as to create jobs for many African countries [102-105]. This shows that the vast field of medicinal plants on the African continent, if harnessed, could rescue the struggling healthcare systems of most such countries Mahomoodally [106]. Some lifesaving medicines like antibiotics have their roots in plants.

\section{Antibiotics}

With the discovery of microorganisms as the causative agents of infectious diseases, many substances including those of plant origin became recognized as "antiseptics". These are substances having the ability to inhibit the growth of microorganisms. Later on, this term was changed to "antibiotics" from the term "antibiosis", which describes antagonism between different species and even between members of the same species in nature [107-110]. An antibiotic is a biochemical drug, derived from one or more kinds of microorganisms. It may have the ability to inhibit the growth of (bacterial static agent) or to kill (bactericidal agent) a number of other microorganisms. This makes antibiotics be of immense value in the treatment of a number of diseases that result from microbial infection Amit et al. [113]. Antibiotics, also known as antimicrobial 
drugs are therefore drugs that fight infections caused by bacteria either by inhibiting the growth of or by destroying these microbes. Their therapeutic success relies on their pharmacokinetic behavior and the contribution that the host's own defenses are able to make towards clearance of the offending microorganism Amit et al. [113].

\section{Bacteriostatic Agents}

After the discovery of Penicillin in 1929, it was a wonder drug and an immediate solution to bacterial infections. Since the several derivatives have discovered or synthetically evolved in laboratories that also led to their categorisation into Bacteriostatic and Bactericidal agents. Bacteriostatic agents are substances that inhibit the growth of other microorganisms by interfering with bacterial protein production, bacterial DNA production and bacterial cellular metabolism (Figure 2). Bacteriostatic antibiotics inhibit growth and reproduction of bacteria without killing them and killing is done by the bactericidal agents. Examples of synthetic bacteriostatic agents include; sulphonamides like furosemide (5), trimethoprim (6), tetracycline (7), chloramophenicol (8) and erythromycin (9) and their derivatives among others Sritharan et al. [114].<smiles>NS(=O)(=O)c1cc(C(=O)O)c(NCc2ccco2)cc1Cl</smiles><smiles>COc1cc(Cc2cnc(N)nc2N)cc(OC)c1OC</smiles>

\section{6}<smiles>CN(C)C1C(O)=C(C(N)=O)C(=O)C2(O)OC3(C)c4cccc(O)c4C(O)=C(O)C3CC12</smiles>

7

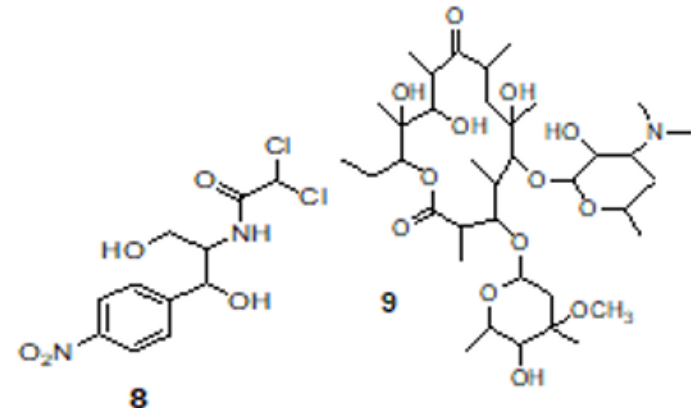

Figure 2: Bacteriostatic agents.

\section{Bactericidal Agents}

Bactericides act as disinfectants, antiseptics or antibiotics (Figure 3). They include; benzylpenicillin (10), cephalosporins like cefalexin (11) and amino-glycosides like gentamicin (12)
(Sritharan and Sritharan, 2004). Effective chemotherapy in the use of antibiotics depends upon selective toxicity, which is their ability to inhibit microorganisms at concentrations tolerated by the host Amit et al. [113].<smiles>CC1(C)S[C@@H]2[C@H](NC(=O)Cc3ccccc3)C(=O)N2[C@H]1C(=O)O</smiles>

10<smiles>CC1=C(C(=O)O)N2C(=O)C(NC(=O)C(N)c3ccccc3)C2SC1</smiles>

11<smiles>CNCC1CCC(N)C(OC2C(N)CC(N)C(OC3OCC(C)(O)C(NC)C3O)C2O)O1</smiles>

12

Figure 3: Bactericidal agents. 


\section{Active Compounds in Plant Extracts}

Plants produce biologically active secondary metabolites often with highly complex chemical structures. These compounds are concerned with survival of the plants and are known to have antimicrobial activity Waterman [115]. The compounds vary from plant to plant and are found to be in different concentrations in different parts of the same plant Lawrence [116]. The combined effects of the health-related challenges due to the rapidly growing population, emergence of antimicrobial resistant pathogenic strains to frequently used commercial drugs such as penicillin, increased side effects, the failure of modern medicine to provide effective treatment, high cost of new drugs and emerging diseases, research into natural products with anti-microbial activity is being pursued in earnest. It is of importance to establish a scientific basis for the use and validation of medicinal plants through biological screening. Populations living in developing countries depend directly on herbal drugs and traditional medicines for primary healthcare WHO [4].

Many of the drugs which are in use today were discovered through their ethno-botanical route Kareru et al. [117]. Moreover, pathogen resistance to existing drugs coupled with increased side effects, lack of curative treatment for several chronic diseases, high cost of drugs and emerging diseases is very common in today's world Humber [14]. This makes it necessary to research on medicinal plants in order to obtain more and potent pharmacological agents owing to the fact that natural products and their related moieties have historically been incredible as a source of therapeutic agents Koehn et al. [118].

\section{Conclusion}

To conclude, let say that phytomedicine is they and loud but the allopathic medicine does not want to hear and say.

\section{References}

1. Evans WC (1997) Trees and Evans Pharmacology 14th Edition London WB, Saunders Company Ltd Fox R. Pharmaceuticals from plants: Great Potential, few funds. Lancet 343: 1513-1515.

2. Farnsworth NR (1998) Human Medicinal Agents from Plants. Kinghorn AD, Balandrin MF (Eds.) ACS symposium series 534: 2-12.

3. Czygan FC (1993) Kulturgeschichte and Mystic des Johanniskruates. Zeitschriftfut Phytotherapie 5: 2676-2682.

4. WHO (2008) Traditional medicine? Fact sheet No. 134.

5. Amin A, Mousa M (2007) Merits of anti-cancer plants from Arabian Gulf region. Cancer Therapy 5: 55-56.

6. Ramawat KG, Goyal S (2008) Bioactive Molecules and Medicinal Plants. Springer, Heidelberg, New York.

7. Abraham RJ, Fisher J, Loftus P (1995) Introduction to NMR spectroscopy. John Wiley and Sons, New York 156: 160-162, 167-168.

8. Adewusi EA, Steenkamp V (2011) In vitro screening for acetylcholinesterase inhibition and antioxidant activity of medicinal plants from southern Africa. Asian Pacific Journal of Tropical Medicine 4(10): 829-835.

9. Agrawal PK (1992) NMR spectroscopy in the structural elucidation of oligosaccharides and glucosides. Journal of Phytochemistry 31(10): 3307-3330.

10. Amiram G, John HC, Lewis KP, Duangchan U, Yoel K, et al. (1997) Novel cytotoxic: Alkylated hydroquinones from Lanneawelwitschii. J Nat Prod 60(2): 116-121.
11. Baker J, Borris RP, Cartel B (1995) Natural drug discovery and development: New perspectives on international collaboration. Journal of Natural Products 58(9): 1325-1357.

12. Ernest R (2005) The efficacy of herbal medicine. Fundam Clin Pharmacol 19(4): 405-409.

13. Jassim SA A, Naji MA (2003) Novel antiviral agents: a medicinal plant perspective. J Appl Microbiol 95(3): 412-427.

14. Humber JM (2002) The role of complementary and alternative medicine: accommodating pluralism. Journal of American Medical Association 288: $1655-1656$.

15. Jiang Y, Wang Y, Yan X (2000) Chinese pharmaceautical Companies: an emerging industry. Drug Discovery Today 6(12): 610-612.

16. Dubey NK, Rajeshkumar S, Tripatti P (2004) Global promotion of herbal medicine: India's opportunity. Current Science 86(1): 37-41.

17. Aue WP, Berthod D, Ernst RR (1976) Two Dimensional Spectroscopy Application to Nuclear Magnetic Resonance. Journal of Chemical Physics 64: 2229-2246.

18. Bingham MG, Willemen A, Wursten BT, Ballings P, Hyde MA (2016) Flora of Zambia: Species information: individual images.

19. Bodenhausen G, Kogler H, Ernst RR (1984) Selection of Coherence transfer Pathways in NMR pulse experiments. Journal of Magnetic Resonance 58(3): 370-388.

20. Busia K (2005) Medicinal provision in Africa: past and present. Phytotherapy Research 19(11): 919-923.

21. Chhabra SC, Uiso FC (1991) Antibacterial activity of some Tanzanian plants used in traditional medicine. Fitoterapia 62: 499-504.

22. Clinical and Laboratory Standards Institute (2013) Performance Standards for Antimicrobial Susceptibility Testing; Twenty-Third Informational Supplement (M100-S23). Wayne 33(1): 100-102.

23. Coxon DT, Holmes A, Ollis WD, Vora VC, Grant MS, et al. (1972) Flavanoldigallates in green tea leaf. Tetrahedron 28: 2819-2826.

24. De Carvalho MG, Suzart LR, Cavatti LC, Kaplan MA C (2008) New flavonoids and other constituents from Ourateahexasperma (Ochnaceae). Journal of Brazilian Chemical Society 19: 1423-1428.

25. Deng JZ, Starck SR, Hecht SM (1999) Bis-5-alkylresorcinols from Panopsisrubescens that inhibit DNA polymerase $\beta$. J Nat Prod 62(3): 477-480.

26. Cragg GM, Newman DJ (2005) Nature: A vital source of leads for anticancer drug development. Phytochemistry Review 8(2): 313-331.

27. De Boer JH, Kool A, Broberg A, Mziray WR, et al. (2005) Anti-fungal and anti-bacterial activity of some herbal remedies from Tanzania. Journal of Ethno-Pharmacology 96(3): 461-469.

28. Fennell CW, Lindsey KL, McGraw LJ, Spar SG, Stafford GI, et al. (2004) Assessing African medicinal plants for efficacy and safety: Pharmacological screening and toxicology. Journal of EthnoPharmacology 94(2-3): 205-217.

29. Balunas MJ, Kinghorn AD (2005) Drug discovery from medicinal plants. Life Science 78(5): 431-441.

30. Correia SJ, David JM, David JP, Chai HB, Pezzuto JM, et al. (2001) Alkyl phenols and derivatives from Tapiriraobtusa. Phytochemistry 56: 781784.

31. Dewick P (1998) Medicinal Natural Products, A Biosynthetic Approach. John Wiley and Sons Ltd, United Kingdom pp. 24-26.

32. Dey PM, Harborne JB (1991) Methods in plant Biochemistry. Academic press. New York, London 7: 370-425.

33. Diallo D, Marston A, Terreaux C, Toure Y, Paulsen BS, et al. (2001) Screening of Malian Medicinal plants for Antifungal, Larvicidal, molluscicidal, antioxidant and radical scavenging activities. Journal of Phytotherapy Research 15(5): 401-406. 
34. Du Y, Oshima R, Yamauchi Y, Kumanotani J, Miyakoshi T (1986) Long chain phenols from the Burmese Lac tree, Melanorrhoeausitate. Phytochemistry 25: 2211-2218.

35. Ebel J, Hahlbrock K (1982) The Flavonoids, Advances in Research. Harborne JB, Mabry TJ (Eds.) Chapman and Hall, London pp. 614-675.

36. El Gammal AA, Mansour RM A (1986) Antimicrobial activities of some flavonoid compounds. Zentrablatt fur Mikrobiologie 141(7): 561-565.

37. Englert G (1985) NMR of Carotenoids, New Experimental Techniques. Pure and Applied Chemistry 57(5): 801-820.

38. Koehn FE, Carter GT (2005) The evolving role of natural products in drug discovery. Nat Rev Drug Discov 4(3): 206-220.

39. Nature Review Drug Discovery. Nature Reviews 4(3): 206-220.

40. Farthings M (2002) Novel Targets for the Control of Secretory Diarrhoea. Gut 50: 15-18.

41. Finney DJ (1964) Statistical method in biological assay. $2^{\text {nd }}(E d n$.$) Charles$ Griffin \& Co Ltd, London 21(58): 1-5.

42. Freudenberg K, Cox RF B, Braun E (1932) The catechin of cacao bean. Journal of American Chemical Society 53(2): 727-728.

43. Gathirwa JW, Rukunga GM, Mwitari PG, Mwikwabe NM, Kimani CW, et al. (2011) Traditional herbal antimalarial therapy in Kilifi district, Kenya. J EthnoPharmacology 134(2): 434-442.

44. Gathirwa JW, Rukunga GM, Njagi EN, Omar SA, Mwitari PG, et al. (2008) The in vitro anti-plasmodial and in vivo anti-malarial efficacy of Combinations of some Medicinal Plants used traditionally for the treatment of Malaria by the Meru Community in Kenya. Journal of EthnoPharmacology 115(2): 223 - 231.

45. Geissler PW, Harris SA, Prince RJ, Oslen A, Achieng' Odhiambo R, et al (2002) Medicinal plants used by Luo mothers and children in Bondo district, Kenya. Journal of Ethno-Phamarcology 83(1-2): 39-54.

46. Geissman TA, Crout DH G (1969) Organic Chemistry of Secondary Plants Metabolism. Free Cooper Company, California pp 185-230.

47. Chhabra SC, Mahunnah RLA, Mshiu EN (1987) Plants used in traditional medicine in Eastern Tanzania. I. Pteridophytes and angiosperms (Acanthaceae and Canellaceae). J EthnoPharmacology 21(3): 253-277.

48. Groweiss A, Cardellina JH, Pannell LK, Uyakul D, Kashman Y, et al. (1997) Novel Cytotoxic, Alkylated Hydroquinones from Lanneawelwitschii. Journal of Natural Products 60(2): 116-121.

49. Harborne JB (1967) Comparative Biochemistry of the Flavonoids. Academic press, London pp. 267-279.

50. Thomson WA R (1978) Healing Plants. Mc Grawhill Book Co. Ltd, London.

51. Geddes AM (1985) The Scientific Basis of Antimicrobial Chemotherapy. Greenwood FO 0 Grady (Eds.), Cambridge University Press, Cambridge 1: $1-12$.

52. Harborne JB (1998) Phytochemical Methods: A guide to modern technique of plant analysis. Chapman and Hall, London.

53. Hilliard JJ, Krause HM, Bernstein JI (1995) A Comparison of Active Site Binding for Quinolones and Novel Flavone Gyrase Inhibitor to DNA Gyrase. Advanced Medical Biology 390: 59-69.

54. Hiroyuki N, Yoshahisa T, Naonobu T, Koichiro T, Hirofumi S, et al. (2006) Antibacterial, Antifungal and Phytochemical Screening of The Plant Species Lannea schweinfurthii Journal of Natural Products 69: 1177.

55. Hirschhorn N (1980) Treatment of acute diarrhoea in children: An historical and physiological perspective. American Journal of Clinical Nutrition 33(3): 637-663.

56. Islam T, Tahara S (2000) Dihydroflavonols from Lanneacoromandelica. Phytochemistry 54(8): 901-907.

57. Islam T, Ito T, Sakasai M, Tahara S (2002) Zoosporidal Activity of Polyflavonoid tannin Identified in Lanneacoromandelica stem bark against phytopathogenic Oomycete Ashanomycescochlioides. Journal of Agricultural and Food Chemistry 50(23): 6697-6703.
58. Jawetz E, MelnickJL, Adelberg EA (1966) Review of medical Microbiology. $7^{\text {th }}$ (Edn.). Lange Medical Publications, London pp. 115-134.

59. Johns T, Faubert GM, Kokwaro JO, Mahunnah RL A, Kimanani EK (1995) Anti-giardial activity of gastrointestinal remedies of the Luo of EastAfrica. Journal of Ethno-Pharmacology 46(1): 17-23.

60. Kapche GD WF, Laatsch H, Fotso S, Kouam SF, Wafo P, et al. (2007) Lanneanol: A new cytotoxic dihydroalkylcyclohexenol and Phenolic Compounds from Lanneanigritana (Sc. Ell.) Keay. Biochemical Systematics and Ecology 35(8): 539-543.

61. Kareru PG, Kenji GM, Gachanja AN, Keriko JM, Mungai (2007) Traditional medicines among the Mbeere people of Kenya. African Journal of Traditional, Complementary and Alternative Medicines 4 (1): 75-86.

62. Kessler H, Bermel W, Griesinger C (1985) Recognition of NMR spin systems of cyclosporine A via heteronuclear proton-carbon long range coupling. Journal of American Chemical Society 107(4): 1083-1084.

63. Koehn FE, Carter GT (2005). Nature Reviews Drug Discovery 4(3): 206220.

64. Kokwaro JO (1990) Medicinal plants of East Africa $2^{\text {nd }}(E d n$.$) . Kenya$ Literature Bureau, Nairobi, Kenya 44(3): 369-381.

65. Kokwaro J0 (1996) An ethnobotanical study of East African Medicinal plants and Traditional Medicine. Science Symposium. Baltimore, Maryland p. 23-24.

66. Sneader W (1985) Drug discovery: The evolution of modern medicine, John Wiley and Sons, New York, p. 1-14.

67. Ji HF, Li XJ, Zhang HY (2009) Natural products and drug discovery. Can thousands of years of ancient medical knowledge lead us to new and powerful drug combinations in the fight against cancer and dementia? EMBO Reports 10(3): 194-200.

68. Sahoo N, Manchikanti P, Dey S (2010) Herbal drugs: Standards and regulation. Fitoterapia 81(6): 462-471.

69. Li J, Vederas JC (2009) Drug discovery and natural products: End of an era or an endless frontier? Science 325(5937): 161-165.

70. Pandian MR, Banu GS, Kumar G (2006) A study of antimicrobial activity of Alangiumsalviifolium. Indian Journal of Pharmacology 38(3): 203204.

71. Krishnaswamy NR (2003) Chemistry of natural products: A Laboratory Handbook. Orient Blackswan publisher, Hyderabad, India p. 75-78.

72. Leuck E (1980) Antimicrobial food additives. Springer - Verlag, Berlin pp. 233-234.

73. Lia Y, Fang H, Xu W (2007) Recent advance in the research of flavonoids as anticancer agents. Minimum Review Medical Chemistry 7(7): 663678.

74. Lin YM, Anderson H, Flavin MT, Pai YH S, Mata-Greenwood E, et al. (2001) Invitro anti-HIV activity of Biflavonoids isolated from Rhus succedanea and Garcinia multiflora. Journal of Natural Products 60(9): 884-888.

75. López Lázaro M (2002) Flavonoids as anticancer agents: structureactivity relationship study. Current Medicinal Chemistry- Anti-Cancer Agents 2(6): 691-714

76. Machocho AK (1992) Flavonoids from the roots of Tephrosiaemoroides and their antifeeding effects on the Larvae of the spotted stalk borer, Chilopartellus, MSc, Thesis, Kenyatta University, Kenya.

77. Mahato SB, Kundu A (1994) 13C NMR spectra of pentacyclic triterpenoids - A compilation and some salient features. Journal of Phytochemistry 37(6): 1517-1575.

78. Maregesi S, Van Miert S, Pannecouque C, Haddad MHF, Hermans N, et al. (2010) Screening of some Tanzanian medicinal plants against Plasmodium falciparum and human immunodeficiency virus. Planta Medica 76(2): 195-201.

79. Mark KR, Chari VM (1986) In "Flavonoids, Advances in Research" Harborne JB (Eds.). Chapman and Hall, London, p. 23-53. 
80. Mckane L, Kandel J (1996) Microbiology: Essentials and applications. 2nd Ed. McGraw-Hill Inc, New York pp. 375-406.

81. Muriithi AW (1996) Control of diarrhoea disease programmes, The Kenyan situation. African Medical Journal 281: 189-195.

82. (1999) National Committee for Clinical Laboratory standards (NCCLS) Performance Standards Antimicrobial susceptibility testing. 9th International Supplement. M100 S9, Wayne PA.

83. National Committee for Clinical Laboratory standards (NCCLS) (2003). Standardization of antimicrobial susceptibility testing by disc diffusion: Standard approved, $8^{\text {th }}$ (Edn.) p. 23.

84. Okoth DA (2014) Phytochemistry and bioactive natural products from Lanneaalata, Lannearivae, Lanneaschimperi and Lanneaschweinfurthii (Anacardiaceae), Phd, Thesis, KwaZulu-Natal University, South Africa.

85. Queiroz EF, Kuhl C, Terreax C, Mavi S, Hostettmann K (2003) New Dihydroalkylhexenones from Lanneaedulis. Journal of Natural Products 66(4): 578-580.

86. Hans GS (1993) General Microbiology $7^{\text {th }}$ (Edn). Cambridge University Press, New York p. 69-377.

87. Radovanović A, Radovanović BB, Jovančićević B (2009) Free radical scavenging and antibacterial activities of southern Serbian red wines. Journal of Food Chemistry 117(2): 326-331.

88. Rao GN, Kumar PM, Dhandapani VS, Krishna TR, Hayashi T (2000) Constituents of Cassiaauriculata. Fitoterapia 71(1): 82-83.

89. Rao KV, Sreeramulu K, Venkata RC, Gunasekar D, Martin MT, et al. (1997) Two new biflavonoids from Ochnaobtusata. Journal of Natural Products 60(6): 632-634.

90. Reddy BA K, Reddy NP Gunasekar D, Blond A, Bodo B (2008) Biflavonoids from Ochnalanceolata. Phytochemistry 1(1): 27-30.

91. Gullece M, Aslan A, Sokmen M, Sahin F, Adiguzel A, et al. (2006) Screening of the antioxidant and antimicrobial properties of the lichens Parmeliasaxatilis, Platismatiaglauca, Ramalinapollinaria, Ramalinapolymorpha and Umbilicarianylanderian. Phytomedicine 13(7): 515-521.

92. Maregesi SM, Pieters L, Ngassapa OD, Apers S, Vingerhoets R, et al. (2008) Screening of some Tanzanian medicinal plants from Bunda district for antibacterial, antifungal and antiviral activities. Journal of Ethno-Pharmacology 119(1,2): 58-66.

93. Cos P, Vlietinck AJ, Berghe DV, Maes L (2006) Anti-infective potential of natural products: how to develop a stronger in vitro 'proof-of-concept'. J EthnoPharmacology 106(3): 290-302.

94. Ruffo CK, Birnie A, Tengnas B (2002) Edible wild plants of Tanzania. Regional Land Management Unit, Nairobi.

95. Satomi F, Naomichi T, Masateru O, Alaa MN, Toshihiro N, et al. (2002) Two novel long chain alkanoic acid esters of lupeol from Alecrimpropolis. Chemical and Pharmaceutical Bulletin 50(3): 439-440.

96. Shadomy S, Espinel Ingroff A, Cartwright R (1985) Laboratory studies with antifungal agents; Susceptibility tests and bioassays. In: "Manual of clinical Microbiology, $4^{\text {th }}$ (Edn. )", Lennette EA, Balows A, Hausler WJ, Shadomy HJ (Eds.), McGraw-Hill Inc, New York pp. 991-999.

97. Shoskes DA, Zeitklin SI, Shared A, Rajfer J (1999) Quercetin in men with category (III) chronic prostatitis. A preliminary prospective, doubleblind, placebo-controlled trial. Urology 54(6): 960-963.

98. Silverstein R, Bassler G, Morrill T (1991) Spectroscopic identification of Organic Compounds, John Wiley and Sons, New York pp. 119-228.

99. Singh S, Singh GB (1996) Hypotensive activity of Lanneacoromandelica bark extract. Phytotherapy Research 10(5): 429-430.
100. SubramanianSS, NairAGR(1971) PolyphenolsofLanneacoromandelica Journal of Phytochemistry 10(8): 1939-1940.

101. Dutra CA, Campos MM, Santos ARS, Calixtoe JB (2016) Review: Medicinal plants in Brazil: Pharmacological studies, drug discovery, challenges and perspectives. Pharmacological Research 112: 4-29.

102. Summers MF, Marzili LG, Bax A (1986) Complete $1 \mathrm{H}$ and $13 \mathrm{C}$ assignment of Co-enzyme B12 through the use of new two-dimensional NMR Experiment. Journal of American Chemical Society 108(15): 4285-4294.

103. Swartz GV (2006) Phytochemical studies of Herichrysumpatulum MSc, Thesis, University of the Western Cape Town, South Africa.

104. Tait Kamradt A, Davies T, Appelbaum PC, Depardieu F (2000) Two new mechanisims of macrolide resistance in clinical strains of Streptococcus pneumoniae from Eastern Europe and North America. Journal of Antimicrobial Agents 44(12): 337-340.

105. Venkata RK, Venkata RR (2008) Traditional medicine used by the Adivasis of the eastern Ghat, Andhra Pradesh- for bone fractures. Ethnobotnical Leaflets 12:19-22.

106. Mahomoodally MF (2013) Traditional Medicines in Africa: An Appraisal of Ten Potent African Medicinal Plants. Evidence-Based Complementary and Alternative Medicine.

107. Waterman PG (1992) Role of secondary metabolites in plants in: Chadwik DJ, Whelman J (Eds.). Secondary metabolites, their function and evolution. Ciba Foundation Symposium 171. Chichester: Wiley 225-275.

108. Watt JM, Beyer Brandwijk MG (1962) Medicinal and poisonous plants of Southern and Eastern Africa, $2^{\text {nd }}$ (Edn.), Livingstone ES Ltd, Edinburg 46: 205-297.

109. Werner RA, Rossmann A, Schuarz C, Bacher A, Schmidt HL, et al. (2004) Biosynthesis of gallic acid in Rhys typhina: discrimination between alternative pathways from natural oxygen isotope abundance. Phytochemistry 65(20): 2809-2813.

110. Xu JZ, Yeung SY V, Chang Q, Huang Y, Chen Z (2004) Comparison of antioxidant activity and bioactivity of tea epicatechins with their respective epimers. British Journal of Nutrition 91(6): 873-881.

111. Yun XJ, Shu HM, Chen GY, Ji MH, Ding JY (2014) Chemical constituents from barks of Lanneacoromandelica. Chinese Herbal Medicines 6(1): 65-69.

112. Papuc C, Goran GV, Predescu CN, Nicorescu V, Stefan G (2017) Plant Polyphenols as Antioxidant and Antibacterial Agents for Shelf-Life Extension of Meat and Meat Products: Classification, Structures, Sources, and Action Mechanisms. Comprehensive Reviews in Food Science and Food Safety 16: 1243-1268.

113. Amit RN, Shailendra S (2005) Ethno-Medicinal Approach in Biological and Chemical Investigation of Phytochemicals as Antimicrobials. Pharma information $4: 2$.

114. Sritharan M, Sritharan V (2004) Emerging problems in the management of Infectious diseases. The Biofilm. Indian Journal of Medical Microbiology 22(3): 140-142.

115. Carlton RR, PG Waterman, AI Gray, SG Deans (1992). The antifungal activity of the leaf gland volatile oil of sweet gale (Myrica gale) (Myricaceae). CHEMOECOLOGY 3(1): 55-59.

116. Lawrence BM (2001) Essential Oils: From Agriculture to chemistry. Introduction Journal of Aromather 10(3-4): 82-98.

117. Kareru PG, Gachanja AN, Keriko JM, Kenji GM (2007) Antimicrobial activity of some medicinal plants used by herbalists in Eastern province, Kenya. Afr J Tradit Complement Altern Med 5(1): 51-5.

118. Koehn FE, Carter GT (2005). Nature Reviews Drug Discovery 4(3): 206-220. 


\section{ISSN: 2574-1241}

DOI: 10.26717.BJSTR.2019.14.002511

Amuka 0.Biomed J Sci \& Tech Res

(C) This work is licensed under Creative

Submission Link: https://biomedres.us/submit-manuscript.php

$\begin{array}{ll}\text { BIOMEDICAL } & \text { Assets of Publishing with us } \\ \text { RESEARCHES } & \text { - Global archiving of articles } \\ & \text { - Immediate, unrestricted online access } \\ & \text { - Rigorous Peer Review Process } \\ \end{array}$

